\title{
GENETIC DIVERSITY OF A BRAZILIAN WINE GRAPE GERMPLASM COLLECTION BASED ON MORPHOAGRONOMIC TRAITS ${ }^{1}$
}

\author{
PATRÍCIA COELHO DE SOUZA LEÃO², COSME DAMIÃO CRUZ ${ }^{3}$, \\ SÉRGIO YOSHIMITSU MOTOIKE ${ }^{3}$
}

\begin{abstract}
The objectives of this study were to evaluate the performance of cultivars, to quantify the variability and to estimate the genetic distances of 66 wine grape accessions in the Grape Germplasm Bank of the EMBRAPA Semi-Arid, in Juazeiro, BA, Brazil, through the characterization of discrete and continuous phenotypic variables. Multivariate statistics, such as, principal components, Tocher's optimization procedure, and the graphic of the distance, were efficient in grouping more similar genotypes, according to their phenotypic characteristics. There was no agreement in the formation of groups between continuous and discrete morpho-agronomic traits, when Tocher's optimization procedure was used. Discrete variables allowed the separation of Vitis vinifera and hybrids in different groups. Significant positive correlations were observed between weight, length and width of bunches, and a negative correlation between titratable acidity and TSS/TTA. The major part (84.12\%) of the total variation present in the original data was explained by the four principal components. The results revealed little variability between wine grape accessions in the Grape Germplasm Bank of Embrapa Semi-Arid.
\end{abstract}

Index terms: germplasm, grapevine, grape cultivars, Vitis spp., multivariate analysis.

\section{DIVERSIDADE GENÉTICA DE UMA COLEÇÃO BRASILEIRA DE UVAS PARA VINHO BASEADA EM CARACTERES MORFOAGRONÔMICOS}

RESUMO - Os objetivos deste trabalho foram avaliar o comportamento agronômico, quantificar a variabilidade e estimar as distâncias genéticas de 66 acessos de videira destinadas à elaboração de vinhos, presente no Banco de Germoplasma de Videira da EMBRAPA Semiárido, em Juazeiro-BA, Brasil, por meio da caracterização de descritores fenotípicos de variação contínua e discreta. As técnicas multivariadas utilizadas, componentes principais, método de otimização de Tocher e projeção gráfica das distâncias foram eficientes no agrupamento dos genótipos mais similares, de acordo com as suas características fenotípicas. Não houve concordância na formação dos grupos pelo método de otimização de Tocher, quando foram avaliadas características morfoagronômicas de variação contínua e discreta. A utilização de variáveis discretas permitiu a separação de Vitis vinifera e híbridos em grupos distintos. Correlações significativas positivas foram observadas entre peso, comprimento e largura de cachos, bem como correlação negativa entre acidez total titulável e relação SST/ATT. $84,12 \%$ da variação total presente nos dados originais foram explicados pelos primeiros quatro componentes principais. Os resultados obtidos demonstram que existe pequena variabilidade entre os acessos de uvas para vinho no Banco de Germoplasma da Embrapa Semiárido.

Termos para indexação germoplasma, videira, cultivares, Vitis spp., análise multivariada.

\footnotetext{
${ }^{1}$ (Trabalho 235-09). Recebido em: 14-10-2009. Aceito para publicação em: 21-05-2010.

${ }^{2}$ Researcher (D.Sc.) - Embrapa Semi-Árido, BR 428, Km 152, Zona Rural, CEP:56300-970, Petrolina-PE, C.P.: 23 e-mail: patricia@cpatsa.embrapa.br

${ }^{3}$ Professor (D.Sc.) - Universidade Federal de Viçosa, Câmpus Universitário, Centro, CEP: 36570000 - Viçosa-MG, Brasil. e-mail: cdcruz@ufv.br, motoike@ufv.br
} 


\section{INTRODUCTION}

The wine industry in São Francisco River Valley had a great evolution in the recent years, there are now seven wineries installed and the planted area is greater than 800 ha, which produced in 2007, eight million liters of wine, representing $20 \%$ of the national production (SEBRAE, 2007).

The tropical wines known as sun wine are characterized by young wines, fruity and aromatic, which quality is recognized in international competitions and in the most traditional and demanding markets.

The grape industry in this region has evolved into a narrow genetic base, as there are few cultivars of a single species, Vitis vinifera L.. It is worrying from the point of view of sustainability of the grape and wine industry because they are constantly subjected to a high risk of introducing diseases and pests, for which these cultivars are susceptible, resulting in large losses or even in the destruction of vineyards.

The multivariate techniques in the analysis of quantitative and qualitative characteristics have been applied in viticulture in the evaluation of the diversity of genotypes for resistance to diseases (NASCIMENTO et al., 2006) and for morphological, agronomic and biochemical descriptors (MICHELI et al., 1993; CRAVERO et al., 1994, MATHEOU et al., 1995a, 1995b; BOSELLI et al., 2000; COELHO et al., 2004; BORGES et al., 2008). The molecular characterization of $81 \%$ of the accessions of the Embrapa Semi Arid grapevine germplasma bank was performed by Leão et al. (2009), using seven microsatellite markers. The allelic profiles were compared with international databases, allowing the identification of many duplicate accessions, synonyms and name errors, generating a robust database for grape cultivars identification. Borges et al. (2008) analyzed a group of table grapes cultivars of the same germplasma bank by principal components and UPGMA.

The objectives of the present work were to evaluate the performance of cultivars, to quantify variability and to estimate their genetic distances, providing subsidies to guide rational management of the Germplasm Bank of Embrapa Semi-Arid and the cultivars use in grape breeding programs

\section{MATERIAL AND METHODS}

Sixty six wine grape accessions from the Grape Germplasm Bank of Embrapa Semi-Arid were evaluated (Table 1) in the Experimental Field Station of Mandacaru, Juazeiro, State of Bahia, with geographical coordinate, $9^{\circ} 24^{\prime} \mathrm{S}, 40^{\circ} 26^{\prime} \mathrm{W}$, and $365.5 \mathrm{~m}$ (altitude). The climate is classified according to Koeppen, as Bswh, which corresponds to the semi-arid hot, with average annual precipitation of $505 \mathrm{~mm}$, annual average relative humidity of $60.7 \%$, annual average temperature, maximum, and minimum, respectively $26.7^{\circ} \mathrm{C}$, $32.0^{\circ} \mathrm{C}$, and $20.8^{\circ} \mathrm{C}$ (www.cpatsa.embrapa.br/ servicos/dadosmet/cem-anual.html).

The plants were trained in multi-wire vertical trellis and pruned in bilateral cordon. The water was supplied by drip irrigation spaced of $3 \times 2 \mathrm{~m}$. Average data were obtained from four plants of each accession during the period from 2002 to 2007, which corresponded to four cycles.

Nine morpho-agronomic descriptors of continuous variation and six morpho-agronomic descriptors of discrete variation according to the Ipgri (1997) were evaluated: 1) duration of the phenological cycle (D), measured from the date of pruning to harvest (days), 2) production of bunches per plant (P) - weight of all bunches per plant (kg), 3) number of bunches per plant (BP); 4) mean bunches weight (BW) - total weight of all bunches divided by the total number of bunches per plant $(\mathrm{g}), 5$ ) bunches length (BL), measured between the top and bottom of the rachis (cm) 6) width of the bunches (WB), measured between both extremity side of the rachis $(\mathrm{cm}), 7)$ total soluble solids (TSS), determined from a sample of ten berries per bunch in ${ }^{\circ}$ Brix; 8) titratable acidity (TTA), determined from a sample of ten berries per bunch in percentage of tartaric acid /100 $\mathrm{mL}$ of juice; 9) the total soluble solids (TSS)/total titratable acidity (TTA). Five discrete characteristics were also evaluated: 1) consistency of the pulp: crisp, fleshy, muscilaginous, or juicy; 2) Taste: neutral, special, muscat or foxy; 3) Format of the bunches: cylindrical, cylindrical winged or cone; 4) Format of the berries: ovoid, globose or elliptical; 5) Color: Black, red, green or green-yellow.

Statistical analysis was performed using the software Genes 2007.0.0 (CRUZ, 2008). To carry out the multivariate analysis, the genetic distances between all pairs of accessions were obtained using the mean Euclidean distance as a measure of the dissimilarity for the quantitative variables and the index of dissimilarity for the discrete variables. Cluster analysis was performed by Tocher's optimization 
procedure. Diversity was also analyzed using the method of principal components. The relative importance of characters, used in the discrimination of clusters, was assessed at the discretion of the weight variables in eigenvectors. The eigenvectors and eigenvalues were obtained from the correlation matrix of standardized data of original values. The variables with higher weights were considered of minor importance, since the last eigenvector was associated with an eigenvalue greater than 0.70 (CRUZ et al., 2004).

\section{RESULTS AND DISCUSSION}

\section{variables}

\section{Morphoagronomic traits of continuous}

The means of each cultivar and, average, maximum and minimum per group, according to the method of Tocher, for nine morpho-agronomic traits studied are shown in Table 2. Cluster analysis using the Tocher's optimization procedure allowed the formation of 12 groups (Table 3). Group 1 was composed by 41 accessions (62\%), showing a small variability between wine grape cultivars in the Grape Germplasm Bank. Very different cultivars based on aspects such as genealogy, geographic origin and enological potential, were included in this group. Ninety percent of cultivars are Vitis vinifera L., however, interspecific hybrids, such as 'Mars' and 'Tampa' of the University of Arkanzas and 'Moscato Embrapa' and 'BRS Rubea' developed by Embrapa Uva e Vinho, belonged to the same group. Boseli et al. (2000) evaluated 11 cultivars of white wine grapes in the region of the Campaign in Italy, through clustering analysis and principal components based on 29 leaf measures. They observed the formation of four groups, in the group composed by the cultivars 'Asprinio', 'Falanghina di Benevento' and 'Greco di Tufo' there were significant differences in the wine characteristics, but the cultivars were similar in leaf morphology, suggesting a common phylogenetic origin.

The maximum distance $(\mathrm{d}=3.07)$ was observed between 'Müller Thurgau' (group 5) and 'Barbera' (group 1), while the minimum $(\mathrm{d}=0.24)$ was obtained between 'Regner' and 'Romania', both in group 1. The selection of parents for hibridization in a breeding program should consider not only the genetic divergence among accessions, but also their agronomic performance and characteristics.

The group 12, represented by 'BRS Lorena', had the longer phenological cycle, 138 days, while 'Siegerrebe' in group 9, was the earliest cultivar, harvested 87 days after pruning. Group 4 stood out for its higher average production per plant and group
5 for presenting larger bunches (weight, length and width), and soluble solids content (TSS). 'Pedro Ximenez' in group 11 and 'Campanario' in group 7 showed respectively the highest and lowest value for total acidity. On the other hand, the best TSS / TTA ratio was observed in group 4.

The principal component analysis showed that four components are necessary to explain $84.12 \%$ of the total variation and was used to plot the accessions in the three-dimensional space (Figure 1). The principal component 1 explained $36.67 \%$ of the total variance, associated with bunches size characteristics (weight, length and width). The component 2 , representing $18.66 \%$ of the variance, was associated with the chemical characteristics of the grape (TSS/TTA, TTA and TSS). The component 3 , explaining $15.99 \%$ of the variance was correlated with the yield (number of bunches and yield per plant). Finally, the main component 4, explaining $12.79 \%$ of the total variance was correlated with the bunches maturation, because the highest scores were obtained for the duration of the phenological cycle, TSS/TTA, TTA and TSS. Fatahi et al. (2004) analyzed 90 grape varieties using principal components found that seven components were needed to explain $81 \%$ of the total variance, with the first factor was related to the berry characteristics and the second factor was associated with bunches characteristics. Looking at Table 4, it is possible to identify the variables of greatest weight in the last eigenvectors. However, the highest score in the last eigenvector was higher than 0.70 , associated with the characteristic bunches weight, indicating that no trait can be discarded. Borges et al. (2008) obtained eight groups of seeded grape cultivars and one group of seedless grape cultivars by principal componentes in the same germplasm collection. They observed an agreement between the most divergent accessions of seeded and seedless table grapes cultivars by two multivariate methods: principal components and the mean Euclidean distance.

Table 5 showed the existence of positive and significant correlation between different morpho-agronomic traits; however the Pearson's correlation coefficients were very low. The correlation between yield per plant and total acidity was high and positive $(\mathrm{r}=0.88)$, indicating that the higher the yield, the greater the acidity of the berry. Fatahi et al. (2004) obtained a negative correlation between yield per plant and content of soluble solids.

The evaluation of a great number of characters, especially those related to the wine enological characteristics, such as anthocyanins, polyphenols, tannins among others, is necessary not only for a bet- 
ter differentiation of the groups, but also to provide a more complete set of information for the selection of parents based on their phenotypic characteristics. variables

Morpho-agronomic traits of discrete

Cluster analysis by the Tocher's optimization procedure based on five discrete variables resulted in the formation of 8 groups (Table 6). Forty-eight accessions $(72.7 \%)$ were concentrated in group 1, which included the main wine grape cultivars of the Sub Middle São Francisco River basin, such as, 'Cabernet Sauvignon', 'Syrah', 'Chenin Blanc', 'Tannat', 'Ruby Cabernet', among others. Although the groups based on discrete variables are different from those based on quantitative variables, there was a coincidence of $69 \%$ of accessions in group 1 . The group 1 was composed exclusively by cultivars of Vitis vinifera, the hybrids are all separated into distinct groups. The clustering based on morphoagronomic discrete variables allowed the separation between accessions of the specie Vitis vinifera and hybrids, which was not observed in the evaluation of continuous variation traits. According to Martinello et al. (2002), this occurs mainly because the quality characteristics are controlled by few genes and thus are little affected by the environment.

The results of multivariate analysis showed little variation among accessions of wine grape in the Germplasm Bank of Embrapa Semiarid. This can be explained because that collection was composed mainly by classic and traditional cultivars in the international wine market. According to This et al. (2006), there was a significant reduction in genetic diversity of grapevines in the last 50 years as a consequence of the globalization of wine companies and markets, which limited the cultivars to a small number, leading to the disappearance of old local varieties or landraces.

TABLE 1 - Wine grape cultivars, origin and specie evaluated in this work.

\begin{tabular}{lllll}
\hline Acessions & Number & Origin & Specie & Pedigree \\
\hline Altesse & 1 & V. vinifera & France & \\
Ancellotta & 2 & V. vinifera & Italy & \\
Aramon & 3 & V. vinifera & France & \\
Baco Blanc & 4 & V. vinifera & France & Folle Blanche X Noah \\
Barbera & 5 & V. vinifera & Italy & \\
Bordô & 6 & Hybrid & USA & (Isabella X Labrusca) X O.P. \\
BRS Lorena & 7 & Hybrid & Brazil & Malvasia Bianca X Seival \\
BRS Rubea & 8 & Hybrid & Brazil & Niagara Rosada X Bordo \\
Burger & 9 & V. vinifera & Germain & Heunisch x (Vitis sylvestris X Traminer) \\
Cabernet Sauvignon & 10 & V. vinifera & France & Cabernet Franc X Sauvignon Blanc ${ }^{1}$ \\
Campanário & 11 & V. vinifera & Portugal & Camarate Preto X Fernao Pires \\
Carignane & 12 & V. vinifera & France & \\
Castelão & 13 & V. vinifera & Portugal & \\
Chasselas Doré & 14 & V. vinifera & France & \\
Chenin Blanc & 15 & V. vinifera & France & \\
Cinsaut & 16 & V. vinifera & France & \\
Colombard & 17 & V. vinifera & France & Heunisch Weiss X Chenin Blanc \\
Feher Szagos & 18 & V. vinifera & Hungary & \\
Flora & 19 & V. vinifera & USA & Semillon X Traminer \\
Gamay & 20 & V. vinifera & France & Pinot x Heunisch Weiss \\
Gamay Beaujolais & 21 & V. vinifera & France & \\
Gewurztraminer & 22 & V. vinifera & Germain & \\
Grand Noir & 23 & V. vinifera & France & Aramon X Petit Bouschet \\
Grenache & 24 & V. vinifera & Spain & \\
\hline & & & & \\
\hline
\end{tabular}


Continued

\begin{tabular}{|c|c|c|c|c|}
\hline Acessions & Number & Origin & Specie & Pedigree \\
\hline Lassif & 25 & $?$ & $?$ & \\
\hline Malvasia Branca & 26 & V. vinifera & Portugal & \\
\hline Malvasia Chartrense & 27 & $V$. vinifera & $?$ & \\
\hline Malvasia di Lipari & 28 & $V$. vinifera & Italy & \\
\hline Mars & 29 & Hybrid & USA & Island belle X A1339 \\
\hline Moscato Embrapa & 30 & Hybrid & Brazil & Couderc 13 X July Muscat \\
\hline Moscato di Canelli & 31 & V. vinifera & Italy & Muscat de Alexandria X? \\
\hline Mouverdre & 32 & $V$. vinifera & Spain & \\
\hline Muller Thurgau & 33 & V. vinifera & Switzerland & \\
\hline Olivette Noire & 34 & $V$. vinifera & France & \\
\hline Palomino & 35 & $V$. vinifera & Spain & \\
\hline Pedro Ximenez & 36 & $V$. vinifera & Spain & \\
\hline Periquita & 37 & $V$. vinifera & Portugal & \\
\hline Petit Syrah FR & 38 & $V$. vinifera & France & Dureza de Ardeche X Mondeuse Blanche \\
\hline Petit Syrah RS & 39 & $V$. vinifera & France & Dureza de Ardeche X Mondeuse Blanche \\
\hline Petit Verdot & 40 & V. vinifera & France & \\
\hline Peverella & 41 & $V$. vinifera & Italy & \\
\hline Red Vletliner & 42 & V. vinifera & $?$ & \\
\hline Regner & 43 & $V$. vinifera & German & Luglienca Bianca X Gamay Precoce \\
\hline Riesling do Reno & 44 & $V$. vinifera & German & \\
\hline Riesling Itálico & 45 & $V$. vinifera & France & \\
\hline Riesling Renano & 46 & $V$. vinifera & German & \\
\hline Royalty & 47 & $V$. vinifera & USA & Alicante Ganzen X Trousseau \\
\hline România & 48 & $?$ & $?$ & \\
\hline Ruby Cabernet & 49 & $V$. vinifera & USA & Cabernet Sauvignon X Carignan \\
\hline Sangiovese & 50 & $V$. vinifera & Italy & \\
\hline Sauvignon Blanc & 51 & $V$. vinifera & France & Traminer $\mathrm{X}$ ? \\
\hline Seara Nova & 52 & $V$. vinifera & Portugal & Diagalves X Fernao Pires \\
\hline Semillon & 53 & $V$. vinifera & France & \\
\hline Siegerrebe & 54 & $V$. vinifera & German & Madeleine Angevine $\mathrm{x}$ Traminer Rot \\
\hline Souzão & 55 & $V$. vinifera & Portugal & \\
\hline Sylvaner & 56 & $V$. vinifera & Austria & Oesterreichisch Weiss x Traminer \\
\hline Tampa & 57 & Hybrid & USA & Vitis smalliana O.P. X Niagara \\
\hline Tannat & 58 & V. vinifera & France & \\
\hline Tempranillo & 59 & $V$. vinifera & Spain & \\
\hline Tibouren & 60 & V. vinifera & France & \\
\hline Tinta Roriz & 61 & $V$. vinifera & Spain & \\
\hline Tocai Friulano & 62 & V. vinifera & Italy & \\
\hline Riparia do Traviu & 63 & V. riparia & Brazil & \\
\hline Trebbiano Toscano & 64 & $V$. vinifera & Italy & \\
\hline Ugni Blanc & 65 & $V$. vinifera & Italy & \\
\hline Verdea & 66 & $V$. vinifera & France/Italy & \\
\hline
\end{tabular}


TABLE 2 - Means of 66 wine grape cultivars, according to the Tocher cluster analysis, considering nine characters of continuous variation.

\begin{tabular}{|c|c|c|c|c|c|c|c|c|c|c|}
\hline Acessions & Group & D & $\mathbf{P}$ & BP & BW & BL & WB & TSS & TTA & TSS/TTA \\
\hline Altesse & 1 & 109 & 3.44 & 45 & 94 & 10.01 & 5.37 & 19.50 & 0.70 & 29.50 \\
\hline Ancelota & 1 & 119 & 1.63 & 37 & 87 & 10.13 & 5.20 & 20.18 & 0.55 & 37.90 \\
\hline Baco Blanc & 1 & 118 & 1.63 & 15 & 109 & 10.63 & 5.51 & 18.21 & 0.90 & 26.30 \\
\hline Barbera & 1 & 119 & 1.86 & 29 & 89 & 10.80 & 5.25 & 20.05 & 0.69 & 29.44 \\
\hline BRS Rubea & 1 & 103 & 2.98 & 37 & 168 & 15.24 & 7.15 & 21.13 & 0.72 & 36.27 \\
\hline Cabernet Sauvignon & 1 & 133 & 1.45 & 26 & 76 & 9.36 & 5.51 & 13.70 & 1.35 & 21.14 \\
\hline Castelão & 1 & 119 & 6.23 & 37 & 218 & 13.25 & 7.55 & 17.65 & 0.54 & 32.60 \\
\hline Chansselas Doré & 1 & 108 & 5.99 & 38 & 164 & 12.35 & 5.47 & 17.62 & 0.61 & 28.83 \\
\hline Cinsaut & 1 & 119 & 2.88 & 32 & 119 & 12.07 & 5.31 & 19.91 & 0.96 & 23.40 \\
\hline Feher Szagos & 1 & 107 & 2.73 & 14 & 143 & 11.16 & 5.68 & 20.56 & 0.76 & 28.75 \\
\hline Gamay & 1 & 117 & 3.49 & 24 & 204 & 12.27 & 9.40 & 18.67 & 0.74 & 28.36 \\
\hline Gamay Beaujolais & 1 & 116 & 3.45 & 36 & 129 & 10.42 & 7.08 & 19.58 & 0.71 & 29.48 \\
\hline Gewurztraminer & 1 & 120 & 3.30 & 25 & 251 & 14.44 & 7.91 & 19.65 & 0.71 & 35.88 \\
\hline Grenache & 1 & 132 & 3.93 & 43 & 113 & 10.90 & 6.19 & 17.86 & 0.73 & 30.48 \\
\hline Lassif & 1 & 118 & 3.37 & 22 & 209 & 14.35 & 9.58 & 19.99 & 0.59 & 35.86 \\
\hline Malvasia di Lipari & 1 & 101 & 2.69 & 29 & 138 & 11.59 & 6.33 & 17.64 & 0.71 & 27.66 \\
\hline Mars & 1 & 115 & 2.91 & 37 & 107 & 10.60 & 5.78 & 17.11 & 0.51 & 43.59 \\
\hline Moscato Embrapa & 1 & 111 & 2.34 & 26 & 140 & 13.69 & 6.24 & 21.53 & 0.56 & 43.52 \\
\hline Moscato di Canelli & 1 & 126 & 3.49 & 21 & 187 & 13.83 & 6.69 & 19.48 & 0.66 & 31.63 \\
\hline Periquita & 1 & 119 & 1.17 & 9 & 89 & 9.37 & 5.80 & 20.30 & 0.50 & 29.60 \\
\hline Petit Sirah (FR) & 1 & 115 & 3.39 & 35 & 109 & 14.91 & 5.69 & 20.44 & 0.91 & 27.70 \\
\hline Petit Sirah (RS) & 1 & 121 & 2.61 & 27 & 90 & 10.39 & 5.53 & 19.54 & 0.54 & 37.97 \\
\hline Petit Verdot & 1 & 119 & 0.74 & 10 & 126 & 11.75 & 5.75 & 18.50 & 0.74 & 26.18 \\
\hline Peverella & 1 & 123 & 4.70 & 25 & 201 & 17.00 & 6.20 & 20.10 & 0.56 & 36.55 \\
\hline Red Vletliner & 1 & 116 & 3.60 & 19 & 169 & 14.90 & 5.95 & 20.49 & 0.61 & 34.94 \\
\hline Regner & 1 & 119 & 3.45 & 30 & 110 & 11.35 & 5.67 & 18.64 & 0.59 & 31.72 \\
\hline Riesling Itálico & 1 & 116 & 3.00 & 44 & 76 & 9.84 & 4.56 & 18.78 & 0.76 & 26.51 \\
\hline Riesling Renano & 1 & 123 & 2.88 & 46 & 75 & 9.71 & 4.76 & 19.12 & 0.68 & 33.20 \\
\hline România & 1 & 121 & 2.86 & 30 & 107 & 12.83 & 5.80 & 18.42 & 0.58 & 32.24 \\
\hline Ruby Cabernet & 1 & 119 & 1.19 & 20 & 118 & 11.24 & 5.55 & 18.01 & 0.80 & 24.44 \\
\hline Sangiovese & 1 & 129 & 2.40 & 26 & 161 & 13.36 & 5.43 & 19.12 & 0.66 & 33.51 \\
\hline Sauvignon Blanc & 1 & 120 & 2.21 & 23 & 124 & 11.04 & 5.32 & 18.46 & 0.69 & 29.62 \\
\hline Seara Nova & 1 & 119 & 5.19 & 33 & 191 & 14.34 & 7.05 & 19.01 & 0.75 & 29.81 \\
\hline Semillon & 1 & 108 & 3.57 & 34 & 114 & 11.91 & 5.62 & 19.03 & 0.68 & 29.65 \\
\hline Souzão & 1 & 125 & 3.52 & 32 & 142 & 13.36 & 5.86 & 21.00 & 0.67 & 36.69 \\
\hline Sylvaner & 1 & 118 & 4.31 & 54 & 111 & 9.27 & 5.03 & 19.36 & 0.54 & 36.95 \\
\hline Tampa & 1 & 120 & 1.60 & 25 & 99 & 11.36 & 5.65 & 17.15 & 0.82 & 27.63 \\
\hline Tannat & 1 & 121 & 4.16 & 27 & 182 & 12.06 & 6.25 & 19.88 & 0.69 & 30.84 \\
\hline Tibouren & 1 & 130 & 3.82 & 36 & 161 & 14.28 & 7.43 & 17.39 & 0.47 & 38.33 \\
\hline Tocay Fruilano & 1 & 124 & 2.35 & 31 & 130 & 11.70 & 6.55 & 17.70 & 0.57 & 42.42 \\
\hline Trebbiano Toscano & 1 & 132 & 1.17 & 11 & 110 & 11.05 & 5.42 & 18.36 & 0.61 & 31.72 \\
\hline Means & 1 & 119 & 3.02 & 29 & 135 & 12.05 & 6.10 & 18.99 & 0.69 & 31.92 \\
\hline
\end{tabular}

Continue... 
Continued

\begin{tabular}{|c|c|c|c|c|c|c|c|c|c|c|}
\hline Acessions & Group & D & $\mathbf{P}$ & BP & BW & BL & WB & TSS & TTA & TSS/TTA \\
\hline Aramon & 2 & 136 & 3.95 & 24 & 225 & 16.19 & 8.34 & 16.93 & 0.58 & 30.38 \\
\hline Burguer & 2 & 130 & 5.45 & 26 & 269 & 17.23 & 7.32 & 16.74 & 0.71 & 25.26 \\
\hline Carignane & 2 & 133 & 5.71 & 41 & 212 & 14.02 & 6.99 & 17.38 & 0.68 & 25.80 \\
\hline Chenin Blanc & 2 & 132 & 6.37 & 35 & 265 & 14.44 & 6.96 & 18.05 & 0.85 & 26.24 \\
\hline Colombard & 2 & 119 & 5.39 & 51 & 194 & 14.70 & 8.88 & 17.38 & 0.59 & 29.92 \\
\hline Grand Noir & 2 & 129 & 5.17 & 33 & 228 & 15.06 & 7.82 & 19.33 & 0.55 & 41.73 \\
\hline Malvasia Bianca & 2 & 136 & 4.12 & 14 & 365 & 16.63 & 8.45 & 17.43 & 0.51 & 34.36 \\
\hline Malvasia Chartrense & 2 & 126 & 2.84 & 16 & 220 & 16.83 & 8.79 & 18.38 & 0.47 & 39.96 \\
\hline Mouverdre & 2 & 126 & 5.24 & 21 & 300 & 15.74 & 8.89 & 16.53 & 0.47 & 37.73 \\
\hline Ugni Blanc & 2 & 131 & 6.55 & 24 & 240 & 16.76 & 7.32 & 18.91 & 0.53 & 36.67 \\
\hline Verdea & 2 & 133 & 3.55 & 22 & 206 & 16.57 & 6.61 & 20.03 & 0.75 & 42.26 \\
\hline Means & 2 & 130 & 4.94 & 28 & 247 & 15.83 & 7.85 & 17.91 & 0.61 & 33.67 \\
\hline Bordô & 3 & 110 & 0.72 & 4 & 39 & 7.23 & 3.67 & 19.00 & 0.82 & 24.05 \\
\hline Tempranillo & 3 & 119 & 1.20 & 16 & 83 & 9.08 & 5.15 & 21.00 & 0.92 & 24.04 \\
\hline Means & 3 & 115 & 0.96 & 10 & 61 & 8.15 & 4.41 & 20.00 & 0.87 & 24.04 \\
\hline Flora & 4 & 122 & 6.11 & 40 & 180 & 12.88 & 5.77 & 21.09 & 0.53 & 40.72 \\
\hline Tinta Roriz & 4 & 119 & 4.74 & 36 & 126 & 13.97 & 8.37 & 21.73 & 0.44 & 51.11 \\
\hline Means & 4 & 120 & 5.43 & 38 & 153 & 13.43 & 7.07 & 21.41 & 0.49 & 45.92 \\
\hline Muller Thurgau & 5 & 133 & 2.79 & 8 & 421 & 19.06 & 10.92 & 18.01 & 0.49 & 37.22 \\
\hline Palomino & 5 & 118 & 4.85 & 22 & 340 & 19.01 & 11.30 & 17.04 & 0.73 & 27.87 \\
\hline Means & 5 & 125 & 3.82 & 15 & 380 & 19.03 & 11.11 & 17.53 & 0.61 & 32.54 \\
\hline Olivette Noire & 6 & 106 & 4.22 & 16 & 190 & 16.99 & 8.44 & 16.89 & 0.66 & 30.57 \\
\hline Riparia do Traviu & 6 & 110 & 5.27 & 47 & 130 & 14.32 & 10.57 & 18.69 & 0.53 & 30.09 \\
\hline Means & 6 & 108 & 4.74 & 32 & 160 & 15.66 & 9.51 & 17.79 & 0.60 & 30.33 \\
\hline Campanário & 7 & 131 & 4.98 & 46 & 174 & 12.04 & 6.91 & 15.73 & 0.44 & 36.30 \\
\hline Riesling do Reno & 8 & 127 & 0.47 & 8 & 126 & 9.30 & 6.85 & 16.50 & 0.67 & 24.82 \\
\hline Siegerrebe & 9 & 87 & 0.53 & 6 & 174 & 13.85 & 8.90 & 21.38 & 0.48 & 44.25 \\
\hline Roialty & 10 & 120 & 0.92 & 9 & 76 & 9.20 & 4.67 & 20.13 & 0.51 & 42.40 \\
\hline Pedro Ximenez & 11 & 114 & 0.54 & 3 & 158 & 11.03 & 9.00 & 18.13 & 1.11 & 16.3 \\
\hline BRS Lorena & 12 & 138 & 0.99 & 9 & 97 & 9.03 & 5.81 & 17.82 & 0.89 & 43.42 \\
\hline
\end{tabular}

D: Duration of cycle (days between pruning and harvesting); P: yield per plant (Kg); BP: number of bunches per plant; BW: Bunch weight $(\mathrm{g})$; BL: Bunch Length $(\mathrm{cm})$; WB: Bunch Width $(\mathrm{cm})$, TSS: total soluble solids ( ${ }^{\circ}$ Brix); TTA: total titratable acidity $(\%$ TA); TSS / TTA: Relationship ${ }^{\circ}$ Brix/titratable acidity.

TABLE 3 - Grouping according to Tocher's optimization procedure, considering nine continuous variation traits evaluated in 66 wine grape accessions.

\begin{tabular}{|c|c|}
\hline Groups & Acessions \\
\hline & $\begin{array}{llllllllllllllllllllll}43 & 48 & 51 & 5 & 39 & 50 & 58 & 31 & 21 & 53 & 55 & 42 & 2 & 46 & 1 & 45 & 24 & 52 & 62 & 57 & 49 & 18\end{array}$ \\
\hline 1 & $\begin{array}{lllllllllllllllllll}40 & 4 & 28 & 64 & 10 & 16 & 38 & 22 & 20 & 37 & 14 & 29 & 56 & 41 & 60 & 25 & 8 & 30 & 13\end{array}$ \\
\hline 2 & $\begin{array}{lllllllllll}23 & 65 & 66 & 27 & 3 & 32 & 26 & 9 & 12 & 15 & 17\end{array}$ \\
\hline 3 & 659 \\
\hline 4 & 1961 \\
\hline 5 & $33 \quad 35$ \\
\hline 6 & 3463 \\
\hline 7 & 11 \\
\hline 8 & 44 \\
\hline 9 & 54 \\
\hline 10 & 47 \\
\hline 11 & 36 \\
\hline 12 & \\
\hline
\end{tabular}


TABLE 4 - Estimates of eigenvalues $(\lambda)$ and eigenvectors associated with the principal components in 66 wine grape accessions and nine morphological and agronomic traits of continuous variation. Bold values highlight the characteristic of greater weight in their eigenvector.

\begin{tabular}{llllllllll}
\hline \multicolumn{1}{c}{ Traits } & PC 1 & PC 2 & PC 3 & PC 4 & PC 5 & PC 6 & PC 7 & PC 8 & PC 9 \\
\hline D & 0.1824 & 0.2369 & 0.2815 & $\mathbf{0 . 6 1 4 3}$ & -0.5659 & 0.2 & 0.272 & 0.0978 & 0.1011 \\
P & 0.3981 & -0.1157 & 0.4204 & -0.2958 & -0.148 & -0.3069 & 0.0044 & -0.5069 & 0.4368 \\
BP & 0.0921 & -0.3604 & $\mathbf{0 . 6 4 1 1}$ & -0.2829 & 0.014 & 0.3816 & 0.0045 & 0.2999 & -0.3672 \\
BW & $\mathbf{0 . 4 8 4 2}$ & 0.2497 & -0.1483 & -0.06 & -0.1081 & -0.1837 & 0.0312 & -0.2665 & $-\mathbf{0 . 7 4 8 4}$ \\
BL & 0.4839 & 0.0986 & -0.1712 & -0.1884 & -0.1776 & -0.1874 & -0.35970 .6709 & 0.2127 \\
WB & 0.425 & 0.1817 & -0.2561 & -0.1762 & 0.3024 & $\mathbf{0 . 6 6 0 6}$ & 0.3077 & -0.095 & 0.2413 \\
TSS & -0.1064 & -0.4378 & -0.407 & -0.3423 & $-\mathbf{0 . 5 8 3 1}$ & 0.0231 & 0.4157 & 0.0221 & -0.0189 \\
TTA & -0.301 & 0.4484 & 0.028 & -0.361 & -0.42 & 0.3669 & -0.473 & -0.2061 & -0.0026 \\
TSS/TTA & 0.2206 & $\mathbf{- 0 . 5 5 0 3}$ & -0.2229 & 0.3709 & -0.0811 & 0.2824 & $-\mathbf{0 . 5 5 1 7}-0.2653$ & -0.0126 \\
\hline$\lambda$ & $\mathbf{3 . 3 0}$ & $\mathbf{1 . 6 8}$ & $\mathbf{1 . 4 4}$ & $\mathbf{1 . 1 5}$ & $\mathbf{0 . 6 8}$ & $\mathbf{0 . 3 0}$ & $\mathbf{0 . 2 1}$ & $\mathbf{0 . 1 4}$ & $\mathbf{0 . 1 0}$ \\
\hline$\lambda$ (\%) & $\mathbf{3 6 . 6 7}$ & $\mathbf{5 5 . 3 4}$ & $\mathbf{7 1 . 3 4}$ & $\mathbf{8 4 . 1 2}$ & $\mathbf{9 1 . 6 9}$ & $\mathbf{9 4 . 9 8}$ & $\mathbf{9 7 . 2 7}$ & $\mathbf{9 8 . 8 6}$ & $\mathbf{1 0}$ \\
accumulated & & & & & & & & & \\
\hline
\end{tabular}

TABLE 5 - Pearson's correlation coefficients obtained among nine traits, of continuous variation, in 66 wine grape accessions from the Grape Germplasm Bank of EMBRAPA Semi Arid.

\begin{tabular}{lllllllll}
\hline Traits & D & P & BP & BW & BL & WB & TSS & TTA \\
\hline P & $0.19^{\text {ns }}$ & & & & & & & \\
BP & $0.03^{\text {ns }}$ & $0.56^{* *}$ & & & & & & \\
BW & $0.31^{*}$ & $0.53^{* *}$ & $-0.21^{\text {ns }}$ & & & & & \\
BL & $0.18^{\text {ns }}$ & $0.57^{* *}$ & $-0.12^{\text {ns }}$ & $0.84^{* *}$ & & & & \\
WB & $0.06^{\text {ns }}$ & $0.41^{* *}$ & $-0.12^{\text {ns }}$ & $0.76^{* *}$ & $0.74^{* *}$ & & & \\
TSS & $-0.2^{\text {ns }}$ & $0.07^{\text {ns }}$ & $-0.05^{\text {ns }}$ & $0.20^{\text {ns }}$ & $0.26^{*}$ & $0.27^{*}$ & & \\
TTA & $0.005^{\text {ns }}$ & $-0.34^{* *}$ & $-0.20^{\text {ns }}$ & $-0.29^{*}$ & $-0.33^{* *}$ & $-0.36^{* *}$ & $-0.07^{\text {ns }}$ & \\
TSS/TTA & $0.07^{\text {ns }}$ & $0.15^{\text {ns }}$ & $0.18^{\text {ns }}$ & $0.13^{\text {ns }}$ & $0.24^{*}$ & $0.20^{\text {ns }}$ & $0.07^{\text {ns }}$ & $-0.68^{* *}$ \\
\hline
\end{tabular}

$(* *)$ e $(*)$ significant at 1 and $5 \%$ of probability, respectively, by the $t$ test.

TABLE 6 - Grouping according to Tocher's optimization procedure, based on five discrete variables evaluated in 66 wine grape accessions.

\begin{tabular}{|c|c|}
\hline Groups & Acessions \\
\hline 1 & $\begin{array}{llllllllllllllllllllll}1 & 14 & 17 & 22 & 41 & 53 & 62 & 2 & 5 & 10 & 11 & 12 & 38 & 39 & 40 & 49 & 50 & 58 & 3 & 42 & 43 & 44 \\
45 & 52 & 16 & 20 & 21 & 23 & 24 & 32 & 47 & 4 & 18 & 25 & 46 & 51 & 56 & 64 & 65 & 66 & 9 & 15 & 60 \\
28 & 35 & 36 & 19 & 61 & & & & & & & & & & & & & & & & \end{array}$ \\
\hline 2 & $\begin{array}{lllll}6 & 29 & 57 & 63 & 55\end{array}$ \\
\hline 3 & $\begin{array}{llll}13 & 34 & 37 & 59\end{array}$ \\
\hline 4 & $\begin{array}{llll}26 & 30 & 31 & 33\end{array}$ \\
\hline 5 & $27 \quad 54$ \\
\hline 6 & 8 \\
\hline 7 & 7 \\
\hline 8 & \\
\hline
\end{tabular}




\section{CONCLUSIONS}

1- The multivariate statistics to study genetic diversity applied to continuous variable traits (Tocher's optimization procedure and principal components) were consistent with each other.

2- There was no correlation between the formation of the groups using continuous and discrete variables.

3-There is little genetic variability between wine grape accessions in the Grape Germplasm Bank of Embrapa Semi-Arid.

4- Cluster analysis based on morphoagronomic traits resulted in the separation of accessions according to common phenotypic traits.

\section{REFERENCES}

BORGES, R. M. E.; GONÇALVES, N. P. S.; GOMES, A. P. O.; ALVES E. O. S. Divergência fenotípica entre acessos de uvas de mesa no SemiÁrido brasileiro. Pesquisa Agropecuária Brasileira, Brasília, v.43, n.8, p.1025-1030, 2008.

BOSELli, M.; CORSO, C.; MONACO, A. Amplographic characterization of white grape varieties in Campania (Southern Italy) by multivariate analysis. Acta Horticulturae, Wageninge, n. 528, p. 75-81, 2000.

COELHO, I.; CUNHA, J.; CUNHA, J. P.; CARNEIRO, L. C.; CASTRO, R.; EIRA DIAS, J. E. Comparação ampelométrica de populações selvagens de Vitis vinifera e de castas antigas do sul de Portugal. Ciência e Técnica Vitivinícola, Dois Portos, v. 19, n. 1, p. 1-12, 2004.

CRAVERO, M. C.; GUIDONI, S.; SCHNEIDER, A.; STEFANO, R. di. Morphological and biochemical characterisation of coloured berry-muscat grapevine cultivars. Vitis, Siebeldingen, v.33, n.2, p. 75-80, 1994.

CRUZ, C. D.; REGAZZI, A. J.; CARNEIRO, P. C. de $\mathrm{S}$. Modelos biométricos aplicados ao melhoramento genético. 3. ed. Viçosa: UFV, 2004. v. 1, 480 p. CRUZ, C. D. Programa genes: diversidade genética. Viçosa: Editora Viçosa, 2008.

FATAHI, R.; EBADI, A.; VEZVAEI, A.; ZAMANI, Z.; GHANADHA, M. R. Relationship among quantitative and qualitative characters in 90 grapevine (vitis vinifera) cultivars. Acta Horticulturae, Leuven, n. 640, p. 275-282, 2004.
IPGRI - International Plant Genetic Resources Institute. Descriptors for grapevine: Vitis spp. Roma, 1997. $62 \mathrm{p}$.

LEÃO, P. C. de S.; RIAZ, S.; GRAZIANI, R.; DANGL, G. S.; MOTOIKE, S. Y.; WALKER, M. A.Characterization of a Brazilian grape germplasm collection using microsatellite markers. American Journal of Enology and Viticulture, Davis, v.60, n.4, p.517-524. 2009.

MARTINELLO, G. E.; LEAL, N. R.; AMARAL JÚNIOR, A. T.; PEREIRA, M. G.; DAHER, R. F. Divergência genética em acessos de quiabeiro com base em marcadores morfológicos. Horticultura Brasileira, Brasília, v.20, n.1, p.52-58, 2002.

MATHEOU, A.; STAVROPOULOS, N.; SAMARAS, S. Studies on table grape germplasm grown in Northern Greece. I. Maturity time, bunch characteristics and yield. Vitis, Sibeldingen, v.34, n.3, p.155-158, 1995a.

MATHEOU, A.; STAVROPOULOS, N.; SAMARAS, S. Studies on table grape germplasm grown in Northern Greece. II. Seedlessness, berry and must characteristics. Vitis, Sibeldingen, v.34, n.4, p.217-220, 1995 b.

MICHELI, L. de; CAMPOSTRINI, F.; IACONO, F.; STEFANINI, M. Evaluation of genetic divergence among clones by means of phyllometric techniques. Vignevine, Bologna, v.20, n.12, p.64-69, 1993.

NASCIMENTO, A. R. P.; MICHEREFF, S. J.; MARIANO, R. de L. R.; VIANA, I. de O. Reação de clones de videira a Xanthomonas campestris pv. viticola, baseada nos componentes epidemiológicos do cancro bacteriano. Ciência Rural, Santa Maria, v.36, n.1, p.1-7, 2006.

SEBRAE. Vinhos brasileiros: o mundo degusta o Brasil. Porto Alegre, 2007. 44p.

THIS, P.; LACOMBE, T.; THOMAS, M.R. Historical origins and genetic diversity of wine grapes. Trends in Genetics, Kidlington, v.22, p.511-519, 2006. 